\title{
Guidelines for exercise prescription in elderly. Satus and limitations in the south of Italy
}

\author{
C Nisticó ${ }^{*}$, T Iona, M C Papaianni, A Ammendolia \\ From de Senectute: Age and Health Forum \\ Catanzaro, Italy. 5-7 December 2009
}

The elderly are generally less physically active than young adults [1]. In 2007 the American College of Sport Medicine (ACSM) and the American Heart Association (AHA) published an updated recommendation on physical activity specific for older adults that emphasized the role of a regular physical activity [2]. Recently, the U.S. Department of Health and Human Services published national physical activity guidelines that provides guidance about physical activity for adults aged 65 years and older [3]. In particular these guidelines stress that if older adults cannot perform 150 min of moderate-intensity aerobic activity per week because of chronic conditions, they may be physically active based on their abilities and conditions. Despite these recommendations, in Italy data on physical activity and sport practice in the elderly are rather critical. After 65 years old only $9 \%$ of people practice sports and after 75 years old or over this value drops to $2.8 \%$, while physical activity is $21,6 \%$ and $36.3 \%$ respectively. From 65 years old or over more than $50 \%$ people are sedentary and $75 \%$ of 75 year-olds claim no sport or physical activity practice in their leisure time [4]. In the South of Italy, particularly, 40\% of elderly men and $64 \%$ of elderly women don't perform any physical activity in their leisure time. Nevertheless we must consider that a significant part of elderly people living alone have few opportunities to socialize, so their participation in structured exercise programs may be very useful. In Italy the elderly who live alone are 5.6 million and most need help and assistance at home. Actually other countries apply health programs such as Enhance Fitness: a low-cost, evidence-based group exercise program developed specifically for older adults [5]. Based on these considerations we think it's necessary to realize specific physical activities for elderly people,

School of Medicine, Magna Græcia University, Catanzaro, 88100, Italy following the latest scientific recommendations and characteristics: simplicity, safety, economy and efficacy.

Published: 19 May 2010

\section{References}

1. Exercise and Physical Activity for Older Adults.. ACSM 2009.

2. Nelson ME, Rejeski WJ, Blair SN, et al: Physical activity and public health in older adults: recommendation from the American College of Sports Medicine and the American Heart Association. Circulation. 2007, 116(9):1094-105.

3. Physical Activity Guidelines for Americans.. 2008, Rockville (MD): U.S. DHHS.

4. [http://www.istat.it/salastampa/comunicati/non_calendario/20070620_00/ testointegrale.pdf].

5. [http://www.projectenhance.org/ind_enhancefitness.html].

doi:10.1186/1471-2318-10-S1-L41

Cite this article as: Nisticò et al:: Guidelines for exercise prescription in elderly. Satus and limitations in the south of Italy. BMC Geriatrics 2010 10(Suppl 1):L41.

\section{Submit your next manuscript to BioMed Central and take full advantage of: \\ - Convenient online submission \\ - Thorough peer review \\ - No space constraints or color figure charges \\ - Immediate publication on acceptance \\ - Inclusion in PubMed, CAS, Scopus and Google Scholar \\ - Research which is freely available for redistribution \\ Submit your manuscript at www.biomedcentral.com/submit}

